\title{
Tannheilsa í jaðarhópum samfélagsins
}

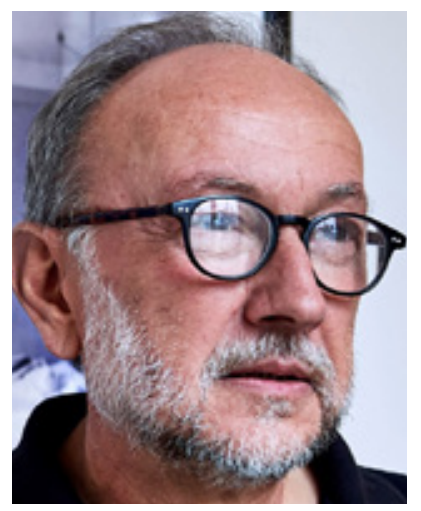

BØRGE HEDE, CAND. ODONT. PH.D. DÓSENT, TANNLAEKNADEILD, HEILBRIGĐIS- OG LAEKNAVÍSINDASVIĐ, KAUPMANNAHAFNARHÁSKÓLA

PATRICIA DE PALMA, CAND.ODONT, MED. DR, TANNLAEKNADEILD, TANNHALDSSVIĐ, KAROLINSKA INSTITUTET KARIN PERSSON, CAND. ODONT. PH.D, PRÓFESSOR Í SAMFÉLAGSTANNLAEKNINGUM, TANNL/EKNADEILD, HÁSKÓLINN Í MALMÖ SATU LAHTI, CAND. ODONT. PH.D, PRÓFESSOR Í SAMFÉLAGSTANNL/EKNINGUM, TANNLAEKNADEILD, HÁSKÓLINN Í TURKU

TENGILIĐUR: BØRGE HEDE, SAXHØJVEJ 26, 2500 VALBY, 0045 52248400, NETFANG: bhe@sund.ku.dk SAMPYKKT AF RITSTJÓRN PEMAVERKEFNIS TIL BIRTINGAR 6. APRÍL, 2020.

TANNLAEKNABLAĐIĐ 2020; 38: 66-72

doi: 10.33112/tann.38.1.7

\section{ÁGRIP}

Einstaklingar á jaðri samfélagsins mynda hópa sem erfitt getur reynst að nálgast og skilgreina. Samhliða pví eru félagsleg vandamál gjarnan til staðar hjá pessum einstaklingum. Í vísindalegu tilliti er áskorun að rannsaka munnheilsutengda pætti hjá jaðarsettum samfélagshópum og kallar sú staðreynd á óhefðbundnar nálganir. Rannsóknir á Norðurlöndunum hafa sýnt fram á nokkrar orsakir fyrir lélegri munnheilsu pessara hópa og hindrarnir hvað varðar meðferð einstaklinga, skipulagningu og stefnumótun. Pörf er á sérsniðnunm áætlunum fyrir tannheilsu jaðarhópa. Háskólar purfa ennfremur að forgangsraða pessu rannsóknarsviði. Í faraldsfræðilegu og einstaklingsbundnu tilliti er munnheilsa pessara hópa mjög slæm og er pörf á bragabót.

Lykilorð: Viðkvæmt pýði, framboð tannlæknispjónustu, munnheilsa, faraldsfræði, rannsóknir á heilbrigðipjónustu. 


\section{Inngangur}

Pótt sýnt hafi verið fram á umtalsvert bætta tannheilsu á Norðurlöndum (1) virðast nokkrir minnihlutahópar ekki njóta pess sama og almenningur. Líf á jaðri samfélagsins getur ekki aðeins leitt til alvarlegra og fjölbreyttra tannheilsuvandamála heldur getur pað einnig haft áhrif á notkun hefðbundinnar tannlæknispjónustu. Pví eru slík vandamál á meðal einstaklinga sem lifa á jaðri samfélagsins meira sláandi en nokkru sinni fyrr og spurningin hvernig hægt er að veita peim tannlæknispjónustu verður æ brýnni.

pessir samfélagshópar eru gjarnan heimilislausir, fíklar, fangar, eða einstaklingar sem pjást af langvinnum geðröskunum. Að sama skapi eru peir samhliða að fást við ýmisleg félagsleg vandamál, s.s. heimilisleysi eða ótraustan húsakost, pörf á flóknum félagslegum stuðningi, vímuefnamisnotkun, geðsjúkdóma, fangavist (annað hvort sem stendur eða áður), auk langvarandi atvinnuleysis, lítillar menntunar og lélegrar fjárhagslegrar stöðu og innflytjendastöðu.

Af pessum sökum er hugsanlegt að hefðbundnar faraldsfræðirannsóknir með dæmigerðu úrtaki séu hvorki hentugar né viðeigandi, sem dregur fram pörfina á óhefðbundinni aðferðafræði, t.d. ólíkum megindlegum og eigindlegum aðferðum til að lýsa og meta íhlutunum.

Hugtök á borð við "heimilislausir" , "fangar" eða "fíklar" geta pví falið í sér of mikla einföldun á einstaklingum sem eru að fást við flókin félagsleg vandamál. Slík flokkun hópa út frá meginvandamáli peirra eða tengslum við stofnanir virðast, prátt fyrir pessa annmarka, vera eina færa leiðin til að nálgast pessa hópa og tannheilsuvandamál peirra.

Afar fáar rannsóknir hafa verið gerðar á tannheilsu jaðarsettra hópa á Norðurlöndunum. Í pessari grein er tekin saman fyrirliggjandi pekking á vandamálum pessa hópa. Par sem samhengi og félagsleg kerfi geta haft mikil áhrif á hegðun einstaklinga (2) er hér aðallega stuðst við rannsóknir frá Norðurlöndunum og að litlu leyti frá öđrum löndum Vestur-Evrópu.

\section{Alvarlegar og langvinnar geðraskanir}

Síðan undið var ofan af stofnanavæðingu í geðheilbrigðispjónustu í kringum 1990 búa flestir einstaklingar með alvarlega geðsjúkdóma einir og piggja göngudeildarstuðning frá geðheilbrigðisstarfsfólki, eða búa í pjónustuhúsnæði. Nánast engar rannsóknir á tannheilsu hafa verið gerðar á einstaklingum sem piggja göngudeildarstuðning og rannsóknir á aðstæðum peirra sem pjást af alvarlegum geðsjúkdómum eru fátíðar $(3,4)$.
Alvarlegir geðsjúkdómar mynda ekki eina greinanlega heild heldur felur mengið i sér ýmsar greiningar, s.s. geðklofa, önnur geðrof, geðhvarfasjúkdóma (tvískautaraskanir) og alvarlegt punglyndi, sem skráđar eru í DSM-5 eđa ICD-10 (DSM, Diagnostic and Statistical Manual of mental disorders eða handbók um greiningu og upplýsingar geđsjúkdóma, ICD International Classification of Diseases eða flokkun sjúkdóma). Alvarlegir geðsjúkdómar valda gjarnan skerðingu á virknigetu sem hefur veruleg áhrif á eða takmarkar eina eða fleiri hliðar daglegs lífs einstaklinga.

Ólíkar ástæður geta legið að baki lélegri tannheilsu einstaklinga með alvarlega geðsjúkdóma. Nokkrir áhrifapættir geta leitt til slæmrar tannheilsu - skert geta á tannhirðu, óreglulegar heimsóknir til tannlæknis, yfirleitt aðeins í neyðartilvikum og langvarandi notkun lyfseðilsskyldra lyfja sem valda munnourrki (5).

Rannsóknir einstaklinga með alvarlega geðsjúkdóma sýna peir skammast sín yfir bví að geta ekki viðhaldið eigin tannheilsu (6). Jafnvel pótt peir vilji sjálfir sinna tannheilsu sinni er hugsanlegt að í samhengi við geðsjúkdóminn hafi hún lítið vægi og forgang. Geðsúkdómur getur valdið pví að tannburstun, sem flestum reynist einföld, reynist peim um megn. Prátt fyrir góđan ásetning í munnhirðu kemst hún oft ekki til framkvæmdar hjá geðsjúklingum (7). Vitað er aðlangvinn lyfjanotkun veldur munnpurrki í pessum hópi sem öðrum (Mynd 1).

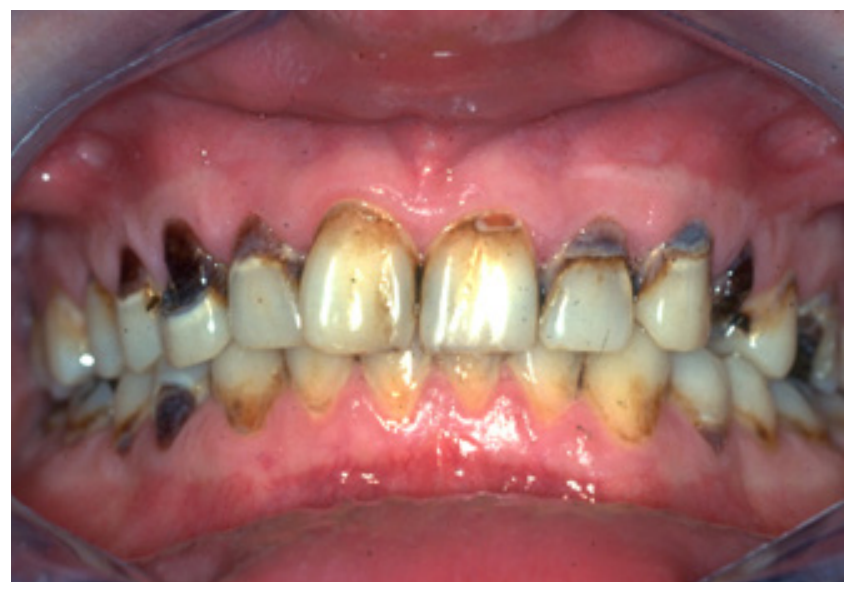

Mynd 1. Karlmaður á prítugsaldri með alvarlegan geðsjúkdóm og dæmigerðar tannhálsaskemmdir tengdum munnpurrki

Pessar aukaverkanir fara ekki aðeins eftir sjálfu lyfinu heldur einnig pví hversu mörg lyf um ræðir. Í sænskri rannsókn á göngudeildarsjúklingum á geðdeild kom í ljós að tæplega priðjungur sjúklinganna notaði tvær eða fleiri gerðir geðlyfja (8). Munnpurrkur er vel pekktur 
áhættupáttur tannskemmda og hjá peim sem hafa alvarlegar og langvinnar geðraskanir eru tannskemmdir og tanntap stærsta tannheilsuvandamálið (5). Aukið algengi tannhaldssjúkdóma hefur ekki verið staðfest.

peir sem búa við alvarlega geðsjúkdóma hafa aukna pörf fyrir tannlæknispjónustu, en flestir leita aðeins til tannlæknis í bráđatilfellum. Í sænskri rannsókn á tannheilsu sjúklinga með alvarlega geðsjúkdóma sem bjuggu i pjónustuhúsnæði kom i ljós að u.p.b 25\% peirra leituðu aðeins til tannlæknis í bráđatilfellum, eða leituðu aldrei aðstoðar tannlæknis (4).

Samantekarrannsókn sem birt var 2011 leiddi í ljós að fólk með alvarlega geðsjúkdóma var 3,4 sinnum líklegra að búa við tannleysi en aðrir (5). Fjölbreytugreining í eldri danskri rannsókn bendir til pess að alvarleg geðröskun valdi fjölgun eins tannflatar á ári í DMFS miðað við aðra (9).

Um 70\% sjúklingar með alvarlega geðsjúkdóma sem bjuggu í pjónustuhúsnæði í Svípjóð (4) reyndust vera með óviðgerðar tannskemmdir. Af pessum 59 sjúklingum (meðalaldur 47 ár) voru fjórir tannlausir. Að meðaltali vantaði 7,3 tennur og tannskemmdastuðullinn (DMFT) var að meðaltali 17,3. Niðurstöður eru birtar í töflu 1.

Tafla 1. Rannsókn sjúklinga með alvarlega geðsjúkdóma sem bjuggu í pjónustuhúsnæði i Svípjóð, út frá aldri, DMT-stuðli, fjölda slitinna tanna og fjölda tapaðra tanna. Fjöldi i hverjum aldurshópi er innan sviga.

\begin{tabular}{cccc}
\hline Aldur & $\begin{array}{c}\text { Meðaltal } \\
\text { DFMT }\end{array}$ & $\begin{array}{c}\text { Meðalfjöldi } \\
\text { slitinna tanna }\end{array}$ & $\begin{array}{c}\text { Meðalfjöldi } \\
\text { tapaðra tanna }\end{array}$ \\
\hline$<35$ ár (8) & 4,6 & 2,7 & 0,3 \\
$35-44$ ár (16) & 15,3 & 4,6 & 3,8 \\
$45-54(18)$ & 18,8 & 5,7 & 4,8 \\
$>55(18)$ & 22,0 & 3,1 & 15,2 \\
\hline
\end{tabular}

Pessar niðurstöður sýna pörf á sérsniðnum stuðningi við tannheilsu, ekki síst fyrir pá sem eru undir 35 ára til að komast hjá tanntapi. Slíkur stuðningur kallar á samstarf félagspjónustu, heilsugæslu, geðheilbrigðispjónustu og tannlæknispjónustu.

Slæm tannheilsa virðist tengd bæði skömm og skorti á stuðningi (5) og pví brýnt að setja markmið að forgangsröðun og getu sjúklinga, pannig að peir sem piggja stuðning geti náð bata. Lykilatriði er að greina getu peirra sem kallar á pjálfun starfsfölks í tannlæknapjónustu en einnig pjálfun fagfólks sem sinnir peim í ólíkum aðstæðum. Áætlun með sérsníðnum stuðningi fyrir yngri einstaklinga sem eru viðkvæmir félagslega og/eða pjást af alvarlegum geðsjúkdómum, ætti að auka líkur á góðri tannheilsu.

\section{Tannheilsa heimilislausra}

Heimilisleysi á sér margar samtengdar orsakir og afleiðingar, bæði félagslega og einstaklingsbundið. Geðsjúkdómar geta bæði verið orsök og afleiðing heimilisleysis. Í Svípjóð hefur farið fram umræða um pað að algengi geðsjúkdóma heimilislausra megi rekja til pess að stofnunum hafi verið lokað.

Vegna alpjóðavæðingar hefur orðið grundvallarbreyting á vinnumarkaði og fjölskyldumynstri á sama tíma og félagsleg tengsl eru veikari en ádur (10). Uppsöfnuð áhrif pessara og annarra samfélagsbreyta eru að einstaklingar eru annaðhvort meðteknir eða útilokaðir, sem getur leitt til heimilisleysis.

Almennt er pessu vandamáli lýst á annan hátt en að tala um atvinnuleysi, húsnæðisskort, aðgreiningu og ójöfnuð. pess í stað eru hin pólitísku skilaboð pau að heimilisleysi sé smávægilegt og umfram allt afmarkað vandamál. Heimilislausum er lýst sem aðskildum hópi í samfélagi sem virkar vel að öðru leyti. Ekki er horfst í augu við félagspólitískar og kerfislægar ástæður fyrir jaðarsetningu og pær eru paggaðar niður. Pess í stað er sjónum beint að afbrigðilegum einstaklingum og hegðun peirra. Svæði með húsnæðisúrræðum eru aðgreind og mörkin milli peirra afar skörp.

Umræðan ætti að snúast um rétt heimilislausra á mannsæmandi lífi með atvinnu, paki yfir höfuðið og heilbrigðispjónustu, par á meðal tannheilsu. Pað getur verið talsvert flókið að ná til heimilislausra sjúklinga (11).

Í gegnum tíðina hafa tannheilsurannsóknir lítið beint sjónum sínum að heimilislausum og fáar vísindarannsóknir á pví sviði birst á Norðurlöndunum (12). Undanfarið hefur fjöldi rannsókna á sérlausnum fyrir sjúklinga á borð við heimilislausa aukist, en fjöldinn er pó langt frá pví nægur til að öðlast góðan skilning á tannheilsu pessa hóps. Samkvæmt De Palma og félögum $(13,14)$ var tannheilsa heimilislausra í Stokkhólmi verri en í eldri rannsóknum frá öðrum löndum.

Meðaltannafjöldi var 18,0 sem er lægri en í samanburðarhópum (15). Tannskemmdastuðullinn DMFT á meðal heimilislausra var hár: 27,0, auk pess sem sjö af átta tannlausum pátttakendum voru ekki með gervitennur. Slímhúđarkvillar voru algengir, s.s. hyperkeratosis, hvítir flekkir og útbreiddur roði. Prátt fyrir að fullorðnir og heimilislausir væru með tiltölulega fáar tennur var tannhaldsástand betra en búast mátti við miðað við munnhirðu.

Pegar gerðar eru áætlanir um tannlæknapjónustu heimilislausra telja De Palma og félagar (16) ekki aðeins 
mikilvægt að líta til reynslu klínískra rannsókna heldur sé lykilatriði að taka mið af hugmyndum og reynslu hinna heimilislausu af margvíslegum ástæðum, pví hætta á varanlegri félagslegri útilokun sé mikil. Helsu væntingar heimilislausra af tannlæknapjónusta voru bætt tyggigeta og útlit. Almennt heilsufar var oft á tíðum bágborið. Alvarlegir, langvinnir og fjölbreyttir sjúkdómar voru til staðar. Meirihluti pátttakenda greindi frá vímuefnamisnotkun og dánartíðni var mun hærri en hjá almenningi.

I Danmörku fundu Øzhayat et al. (17) umtalsvert hærra OHIP-14 gildi (Oral Health Impact Profile, gildi slæmrar tannheilsu) meðal heimilislausra en annarra, sem ekki breyttist milli aldurshópa. Sársauki, streyta, mataræði, slökun, lífið og virkni eru hugtök sem eru vandamál heimilislausra.

Niðurstaða peirra var sú að OHRQoL-gildi (Oral Health Related Quality of Life, lífsgæðakvarði) voru mjög skert meðal heimilislausra en OHIP-14 næstum prefalt hærri en meðal almennings með mikið tanntap og í pörf fyrir laus tanngervi. Önnur dönsk rannsókn (18) sýndi nánast sömu OHIP-14 gildi og meðal sjúklinga í félagslegum áhættuhópi. Nær allir voru með ómeðhöndlaðar tannskemmdir og nær helmingur hafði ekki farið til tannlæknis á undanförnum fimm árum. Eftir sérsniðna meðferð lækkaði OHIP-14 gildið niður á sama stig og hjá sambærilegum hópum almennings.

\section{Vímuefnamisnotkun og tannheilsa}

Vímuefnaraskanir eru skilgreindar sem skaðlegt neyslumynstur áfengis eða annarra vímuefna sem valda skertum lífsgæðum eða afgerandi erfiðleikum (19). Eldri rannsóknir benda til pess að fíklar séu líklegri til að vera með tannskemmdir, og tannhaldssjúkdóma (20).

Algengi ofneyslu áfengis í Evrópu var 42,6\% árið 2016 (21). Í Svípjóð teljast 12,9\% karla og 8,7\% kvenna vera áfengissjúklingar (22). Rannsóknir benda til pess að drykkjusjúkir prói frekar með sér glerungseyðingu, tannhaldsbólgu og aukinn fjölda tannflata með tannátu (23). Fyrir utan glerungseyðingu virðist aukið algengi munnsjúkdóma tengjast versnandi félagslegri stöðu en ekki peim efnum sem eru misnotuð (24).

Um 192 milljón manna í heiminum misnota kannabis. Um 17 milljón manna á aldrinum 15 til 64 ára misnota kannabis í Evrópu. Algengustu tannheilsuvandamál kannabisneytenda eru munnpurrkur, hærri DMFT-gildi og hvítar slímhúđarbreytingar $(25,26)$.

Samkvæmt The World Drug Report 2018 er áætlað að 34,2 milljón manna, 15-64 ára hafi notað amfetamín og metamfetamín. Amfetamín hefur skaðleg og örvandi áhrif á miðtaugakerfið. Við misnotkun metamfetamíns er munnpurrkur eitt algengasta einkenni vegna áhrifa á miðtaugakerfið. Auk pess verður munnvatn sem framleitt er án örvunar próteinríkara. Peir sem misnota efnið verða afar örir en finna sjaldan fyrir svengd eða porsta. Í stað vatns og reglubundinnar næringar halda fíklar sér gjarnan gangandi með neyslu sykraðra gosdrykkja. Tannagnístur, munnpurrkur, próteinríkt munnvatn og aukin neysla gosdrykkja eru allt atriði sem auka líkurnar á tannskemmdum. Einstaklingar sem misnota metamfetamín fá mjög gjarnan alvarlegar tannhaldsbólgur. Hugtakið "spíttkjaftur" (e. meth mouth) hefur náð fótfestu vegna pess hve einkenni spíttneyslu á tennur eru auðpekkjanleg (27) (mynd 2).

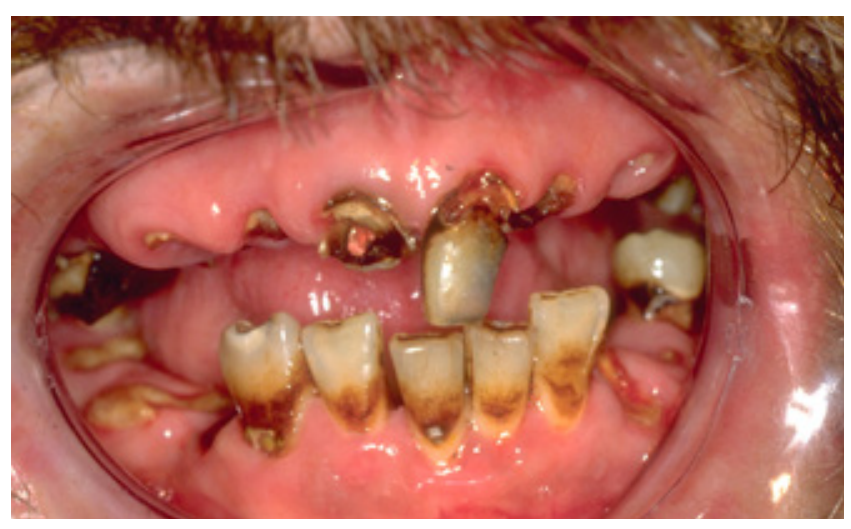

Mynd 2. Dæmi um spittkjaft (e. meth mouth) með alvarlegum tannskemmdum, tanntapi, brotum, glerungseyðingu og öðrum munnholsvandamálum.

Khat er fíkniefni sem virkar á miðtaugakerfið. Ung og fersk laufblöð sem tuggin eru um leið og pau eru tekin af plöntunni skila svipuðum áhrifum og amfetamín. Efnafræðilega er Khat nánast eins og amfetamín. Á Norðurlöndunum er notkun pess aðallega bundin innflytjendum frá Sómalíu og Epíópíu. Khat er ekki aðeins notað í félagslegu samhengi, heldur nota pað margir daglega. Khat getur skilið eftir sig dökkan lit og hvítan áverka par sem tuggið er vegna efna- og núningsertingar. Khatnotkun veldur einnig porsta sem eykur neyslu sykraðra drykkja og aukinnar áhættu á tannskemmdum. Vegna pess að efnið er tuggið, eru tannaslit (e. abrasion) og kjálkaliðsvandamál algeng meðal fíkla. Sterk lykt er af fíkniefninu og græn laufin lita innanverðar kinnar og tungu græna, og tennur stundum brúnar (28).

Heróín er ópíat sem hægt er að reykja, taka í nefið eða sprauta í æð og hefur áhrif á ópíóðaviðtaka í miðtaugakerfi. Tengsl eru á milli heróínfíkla og slæmrar tannheilsu og peir pjást gjarnan af langt gengnum tannsjúkdómum. 
Verkjastillandi áhrif heróíns draga úr tannverkjum og kvíða. Rannsóknir hafa leitt í ljós að algengi tannskemmda og tannhaldssjúkdóma eru meiri hjá heróínfíklum en öðrum (20). Höfundar fundu engar ritrýndra greinar sem fjalla um tengsl tannheilsu og vímuefnamisnotkunar frá neinu Norðurlanda síđustu tuttugu og fimm árin.

\section{Fangar}

Tvær nýlegar rannsóknir frá Norðurlöndunum, ein sænsk og önnur finnsk, fjölluðu um tannheilsu og tengd vandamál hjá föngum. Sænska rannsóknin fjallaði aðeins um karlfanga en sú finnska bæði karl- og kvenfanga $(29,30)$.

Í atferli fanga er ýmislegt sem hefur áhrif á tannheilsu, s.s. vímuefnamisnotkun, en í kerfisbundinni rýni á meðal fanga í 10 löndum hefur komið í ljós að hún er mjög algeng (31). Meðal fanga í Svípjóð reyndust 84\% peirra reykja, $71 \%$ notuðu vímuefni og 13\% misnotuðu áfengi. Meðal fanga í Finnlandi reyktu 88\% daglega, 62\% notuðu vímuefni og 33\% sögðust hafa drukkið áfengi oftar en einu sinni í viku fyrir fangelsisvistun. Vegna lifnaðarhátta fanga verða peir oft fyrir líkamlegum áverkum og pví eru tannbrot og tanntap algeng (32). 51\% sænskra fanga glíma við geðræn vandamál eða ópægindi á borð við kvíða, punglyndi eða svefntruflanir, á meðan 87\% finnskra fanga tóku lyfseðilsskyld lyf og $28 \%$ tóku fjögur lyf eða fleiri, aðallega geðrofslyf (e. antipsychotics), verkjalyf og svefnlyf $(29,30)$.

Tannheilsa fanga reyndist lakari en á meðal almennings í báðum pessum norrænu rannsóknum. 95\% sænskra fanga höfðu tannhaldsbólgu. Allir finnskir fangar voru með tannhaldsbólgu. Meðal sænskra fanga voru 66\% með tannskemmd í a.m.k. einni tönn og 81\% finnskra fanga voru með tannskemmdir. Í Finnlandi voru einnig gerðar rannsóknir á glerungseyðingu og kjálkaliðskvillum (TMD). 90\% fanga mældust með miðlungs eða alvarlega glerungseyðingu. Kjálkaliðskvillar (TMD) voru greindir klínískt í 60\% fanga og einkenni í fundust í 84\% peirra. $(29,30,33,34)$

Í rannsókninni kom fram munur á tíðni tannburstunar hjá sænskum og finnskum föngum $(29,30)$. Í Finnlandi sögðust nánast allir bursta tennur daglega, en í Svípjóð aðeins 7\%. Hugsanlega er hægt að skýra muninn á ólíkum rannsóknaraðferum, og peirri staðreynd að sænsku fangarnir voru spurðir við innlögn en peir finnsku meðan fangelsisvistin stóð yfir. Notkun tannlæknispjónustu var gjarnan mjög óregluleg á meðal fanga. Í Svípjóð sögðust 13\% fara i reglulega skoðun hjá tannlækni en 16\% finnskra fanga. Í Svípjóð sögðu 15\% fanga ástæðu fyrir stopulum tannlæknisheimsóknum vera tannlæknafælni. Í finnsku rannsókninni voru sterk tengls milli tannlæknafælni og óreglulegra tannlæknaheimsókna, sem finnst einnig hjá almenningi (35-38).

Rannsóknir hafa sýnt fram á ýmsar ástæður að baki slæmri tannheilsu meðal fanga. Nýleg rannsókn meðal skoskra fanga fjallað m.a. um hversu flókið orsakasamhengið getur verið (39). Rannsóknin gaf til kynna tvær samhliða og sjálfstæðar millibreytur, vímuefnanotkun og tannlæknafælni. Vímuefnanotkun reyndist vera frumbreyta en tannlæknafælni fylgibreyta á milli punglyndis og tannskemmda. Pegar skipuleggja parf framkvæmd bættrar tannheilsu fanga parf að styðjast við víðtæka nálgun, par sem tekið er tillit til flækjustigs algengra áhættupátta (40).

\section{Sjónarmið}

Alpjóðleg og norræn gögn benda til pess að einstaklingar sem lifa í jaðri samfélagsins standi frammi fyrir ýmsum vandamálum hvað varðar tannheilsu. Bæði er um að ræða einstaklingsbundin vandamál, en einnig vandamál tengdskipulagi og stefnumótun (41). Auk pess benda eldri rannsóknir á Norðurlöndunum til pess að pörf sé á frekari rannsóknum í pessum málaflokki, bæði lýsandi rannsóknum á tannheilsu og rannsóknum sem fylgjast með aðgerðum til bæta tannheilsu pessa hóps. Að auki ættu tannlæknaháskólar að auka kennslu og fræðslu um jaðarhópa, bæði í grunnnámi og framhaldsnámi. Jafnvel pótt pessir hópar pjáist einna mest af tannsjúkdómum er nánast engin kerfisbundin umræða um viðfangsefnið í námskrám háskóla.

Einnig er skortur á sérhæfðri faglegri próun til að auka skilning á vandamálum pessa hópa. Auk pess sýnir pessi rýni fram á brýna pörf á endurskoðun laga og reglugerða til að aðlaga pær betur að pessum viðkvæmu hópum.

Eins og ítrekað hefur komið er pörf á áætlun sem er sérsniðin fyrir pessa hópa og sértökum pörfum peirra fyrir tannlæknispjónustu. Á sumum Norðurlöndum hefur heilbrigðislöggjöfin sérstakar tannheilsuáætlanir sem beinast aðallega að peim sem pjást af alvarlegum geđsjúkdómum, á meðan önnur lönd veita ekki slíka pjónustu.

Frampróun er gjarnan drifin áfram af rannsóknum og skráningu gagna. Sem dæmi má nefna að árið 2013 sampykkti danska pingið priggja ára fjármögnun tannheilsuverkefna ætluð peim sem stóðu illa félagslega. Markmiðið var að koma á fót sérstöku tannheilsuverkefni fyrir pá sem minna mega sín í mörgum sveitarfélögum. Verkefnin í Svendborg og Skive voru á meðal peirra sem voru metin (18). Verkefnin byggðust á samvinnu 
tannlækningastarfsfólks og félagsráðgjafa, fyrirkomulagi með áhugasömu starfsfólki sem hafði bæði skilning á pörf sjúklinga fyrir tannlæknispjónustu og umhverfi sem væri aðlaðandi, aðgengilegt og fordómalaust. OHIP-14 gildi sjúklinga fyrir og eftir meðferð eru birt í töflu 2.

\begin{tabular}{lccc}
\hline & Upphafsgildi & $\begin{array}{c}\text { Lok } \\
\text { meðferðar }\end{array}$ & $\begin{array}{c}\text { P gildi: } \\
\text { Marktektarpróf }\end{array}$ \\
\hline Tal & 1,2 & 0,8 & Ekki marktækt \\
Bragðskyn & 1,2 & 0,8 & $<0,05$ \\
Sársauki innan árs & 2,5 & 0,8 & $>0,001$ \\
Tyggja & 2,6 & 1,1 & $>0,001$ \\
Sjálfsvitund & 3,0 & 1,0 & $>0,001$ \\
Finnur fyrir taugaspennu & 2,5 & 0,9 & $>0,001$ \\
Ófullnægjandi mataræði & 2,1 & 0,9 & $>0,001$ \\
Rofnar máltíðir & 1,6 & 0,7 & $>0,001$ \\
Slökun & 2,1 & 0,6 & $>0,001$ \\
Líður vandræðalega & 3,1 & 1,0 & $>0,001$ \\
Pirringur & 1,1 & 0,3 & $>0,001$ \\
Í vinnu & 1,0 & 0,2 & $>0,001$ \\
Almenn lífsgæði & 2,5 & 0,5 & $>0,001$ \\
Dagleg virkni & 1,4 & 0,2 & $>0,001$ \\
\hline Heildargildi OHIP-14 & 27,8 & 9,9 & $>0,001$ \\
\hline
\end{tabular}

Tafla 2. Upphafsgildi OHIP-14 að meðaltali fyrir og eftir meðferð hjá hópi félagslega viðkvæmra i Danmörku (n=99) (Mann-Whitney-próf).

Pessar niðurstöður, auk niðurstaðna frá öðrum sveitarfélögum, leiddu til viðbótar á dönsku heilbrigðislöggjöfinni vorið 2020, en par var dönskum sveitarfélögum gert skylt að bjóða jaðarsettustu samfélagshópum gjaldfrjálsa tannlæknispjónustu. Petta beinir athygli að ábyrgð tannheilsugeirans almennt, ekki síst háskólasamfélagsins, að setja í forgang rannsóknir á pessu sviði, pví að pessir samfélagshópar pjást verulega af tannsjúkdómum og pað hefur umtalsverð áhrif á lífsgæði peirra.

\section{Heimildir}

1. Christensen LC, Suominen A-L, Hakeberg M, Özkaya F, Klock K, Árnaóttir IB. Social inequality in oral health in the Nordic countries - current status. Tandlaegebladet 2021. Bíður birtingar.

2. Petersen PE, Hakeberg M Inequality in oral health - theoretical approaches. Tandlaegebladet 2021. Bið̋r birtingar.

3. Hede B, Petersen P. E. Self- assessment of dental health among Danish noninstitutionalized psychiatric patients. Spec Care Dent 1992. 12; 33-36

4. Persson K, Stjernswärd, S. Dental health among persons with severe mental illness living in sheltered housing. 2020. (i handriti).

5. Kisely S, Quek L-H, Pais J, Lailoo R, Johnson NW, Lawrence D. Advanced dental disease in people with severe mental illness,: systematic review and metanalysis. BJPsych 2011; 199; 187-93.

6. Persson K, Olin E, Östman, M. Oral health problems and support as experienced by people with severe mental illness living in community- based subsidised housing-a qualitative study. Health Soc Care Community 2010; 18: 529-36.

7. Villadsen DB, Sørensen MT. Oral Hygiene -A Challenge in Everyday Life for People with Schizophrenia. Issues Ment Health Nurs 2017; 38: 643-9.

8. Persson K, Axtelius B, Söderfeldt B, Östman M. Monitoring oral health and dental attendance in an outpatient psychiatric population. Psychiatr Ment HIt.2009; 16: 26371.

9. Hede B. Oral health in hospitalized psychiatric patients in Denmark. Community Dent Oral Epidemiol 1995; 23: 44-8.

10. Tosi, A. The Excluded and the Homeless: The Social Construction of the Fight against Poverty in Europe. İ E. Minigone (ritsti.) Urban poverty and the underclass. bls. 83-104. Oxford: Blackwell. 1996.

11. Howe EG. Organizational ethics' greatest challenge: factoring in less-reachable patients. J Clin Ethics. 1999; 10: 263-70.

12. Hede B. Tandplejens stedbørn - de udsatte og de udstødte.Tandlaegebladet. 2015; 10: 794-801. (á dönsku).

13. De Palma P, Frithiof L, Persson L, Klinge B, Halldin J, Beijer U. Oral health of homeless adults in Stockholm, Sweden. Acta Odontol Scand. 2005; 63:50-5.

14. De Palma P, Nordenram G. The perceptions of homeless people in Stockholm concerning oral health and consequences od denta tretament: a qualitaiv study. Spec Care Dent 2005; 25: 289-95

15. Norderyd O, Koch G, Papias A. et al. Oral health of individuals aged 3-80 years in Jönköping, Sweden during 40 years (1973-2013). II. Review of clinical and radiographic findings. Swed Dent J 2015; 39: 69-86.

16. De Palma P, Nordenram G, Ekman S L. The encounter in dental care as interpreted by homeless individuals. Swed Dent J 2006; 30: 177.

17. Øzhayat EB, Østergaard $P$, Gotfredsen $K$. Oral health-related quality of life in socially endangered persons in Copenhagen, Denmark. Acta Odontol Scand. 2016; 74:6205. doi: 10.1080/00016357.2016.1229022. Epub, 7. september 2016.

18. Hede B, Thiesen H, Christensen LB. A program review of a community-based oral health care program for socially vulnerable and underserved citizens in Denmark. Acta Odont Scand 2019; 77: 364-70.

19. Franck J, Nylander I. Beroendemedicin Lund: Lund : Studentlitteratur AB; 2011. Sverige (á sænsku)

20. Baghaie H, Kisely S,, Forbes M, Sawyer E, Siskind DJ. A systematic review and meta-analysis of the association between poor oral health and substance abuse. Addiction. 2017 May;112 :765-79. doi: 10.1111/add.13754. Epub, 16. mars 2017.

21. World Health Organization. Global Status Report On Alcohol and Health 2018: World Health Organization; Geneva. 2018.

22. Guttormsen U., Gröndahl M. Trender i dryckesmönster : befolkningens självrapporterade alkoholvanor under 2000-talet, Stockholm: The Swedish Council for Information on Alcohol and Other Drugs (CAN); 2017. (á sænsku)

23. Wang J, LV K, Wang W, Jiang X. Alcohol consumption and risk of periodontitis: a meta-analysis, J Clin Periodontol 2016; 43: 572-583.

24. Hede B. Determinants of oral health in a group of Danish alcoholics. Eur J Oral Sci 1996; 104(4): 403-8

25. Darling M R, Aendorf TM. Effects of cannabis smoking on oral soft tissues, Community Dent Oral Epidemiol 1993: 21: 78-81.

26. Joshi S., Ashley M. Cannabis: A joint problem for patients and the dental profession, Br Dent J 2016: 220: 597-601.

27. Stanciu CN1, Glass M, Muzyka BC, Glass OM. „Meth Mouth“: An Interdisciplinary Review of a Dental and Psychiatric Condition. J Addict Med. 2017; 11(4):250-5. doi: 10.1097/ADM.0000000000000316. 
28. Al-Maweri SA, Warnakulasuriya S, Samran A. Khat (Catha edulis) and its oral health effects: An updated review, J Investig Clin Dent 2018: Feb;9(1). doi: 10.1111/ jicd.12288. Epub, 19. ágúst 2017

29. Priwe C, Carlsson. Oral Health Status of Male Swedish Citizens at Admission to Prison. J Correct Health Care. 2018; 24: 382-394.

30. Vainionpää R. Oral health of prisoners. Acta Universitatis Ouluensis. D, Medica 1550. Oulu: University of Oulu, 2019

31. Fazel S, Yoon IA, Hayes AJ. Substance use disorders in prisoners: an updated systematic review and meta-regression analysis in recently incarcerated men and women. Addiction. 2017;112: 1725-1739

32. Viitanen $\mathrm{P} 1$, Vartiainen $\mathrm{H}$, Aarnio J, Von Gruenewaldt V, Hakamäki S, Lintonen $\mathrm{T}$, Mattila AK, Wuolijoki T, Joukamaa M. Finnish female prisoners - heavy consumers of health services. Scand J Public Health. 2013; 41:479-85.

33. Vainionpää R, Peltokangas $A$, Leinonen J, Pesonen P, Laitala ML, Anttonen V. Oral health and oral health-related habits of Finnish prisoners. BDJ Open. 2017; 3: 17006

34. Vainionpää R, Kinnunen T, Pesonen P, Laitala ML, Anttonen V, Sipilä K. Prevalence of temporomandibular disorders (TMD) among Finnish prisoners: cross-sectional clinical study. Acta Odontol Scand. 2019 ; 77: 264-268.
35. Liinavuori A, Tolvanen M, Pohjola V, Lahti S. Longitudinal interrelationships between dental fear and dental attendance among adult Finns in 2000-2011. Community Dent Oral Epidemiol. 2019; 47: 309-315.

36. Åstrøm AN, Skaret E, Haugejorden O. Dental anxiety and dental attendance among 25-year-olds in Norway: time trends from 1997 to 2007. BMC Oral Health. 2011;11:10

37. Hakeberg M, Wide Boman U. Dental care attendance and refrainment from dental care among adults. Acta Odontol Scand. 2017; 75: 366-371.

38. Scheutz F, Heidmann J. Determinants of utilization of dental services among 20- to 34-year-old Danes. Acta Odontol Scand. 2001; 59: 201-11.

39. Arora G, Humphris G, Lahti S, Richards D, Freeman R. Depression, drugs and dental anxiety in prisons: A mediation model explaining dental decay experience. Community Dent Oral Epidemiol. 10. febrúar 2020. Epub, fyrir prentun

40. Watt RG, Sheiham A. Integrating the common risk factor approach into a social determinants framework. Community Dent Oral Epidemiol. 2012;40:289-96.

41. El-Yousfi, Jones K, White S, Marshman Z. A rapid review of barriers to oral healthcare for vulnerable people. Br Dent J 2019; 227: 143-51.

English Summary

\section{Oral health in the margins of the community}

BØRGE HEDE, DDS, PH.D, AFFILIATED ASSOCIATED PROFESSOR, DEPARTMENT OF ODONTOLOGY, FACULTY OF HEALTH AND MEDICAL SCIENCES, UNIVERSITY OF COPENHAGEN, DENMARK

PATRICIA DE PALMA, DDS, MED. DR, CHIEF DENTAL OFFICER/CONSULTANT, DEPARTMENT OF DENTAL MEDICINE, UNIVERSITY DENTAL CARE, KAROLINSKA INSTITUTET, SWEDEN

KARIN PERSSON, RN PH.D, HEADMASTER OF EDUCATION, DEPARTMENT FOR HEALTH AND SOCIETY, UNIVERSITY OF MALMØ, SWEDEN

SATU LAHTI, DDS. PH.D, PROFESSOR OF COMMUNITY DENTISTRY, DEPARTMENT OF COMMUNITY DENTISTRY, UNIVERSITY OF TURKU, FINLAND

ICELANDIC DENTAL JOURNAL 2020; 38: 66-72

doi: 10.33112/tann.38.1.7

Citizens living on the edge of the community form groups which may be difficult to approach and identify. Concurrent social problems are often present at the individual level. From a scientific perspective research on oral health related factors among underserved and socially marginalized groups of citizens, represent methodical challenges which call for alternative approaches. However, from a public health perspective studies from the Nordic countries have identified several causes of poor oral health and barriers to oral care at the individual, the organizational and the policy level. The poor oral health and the lack of sufficient oral care services calls for tailored oral health promotion programs to these groups of vulnerable citizens and underlines and stresses the responsibility of the dental profession in common and the Universities in particular to prioritize this field of research. In the epidemiological as well as in the individual perspective these groups of citizens bear a heavy burden of oral disease - maybe the groups that carries the burden which influence the live of the individual the most.

Keywords: Vulnerable Populations, Delivery of Dental Care, Oral Health, epidemiology, Health Care Research Correspondence: Børge Hede, Saxhøjvej 26, 2500 Valby, 0045 52248400, Mail: bhe@sund.ku.dk

Accepted for publication April 6, 2020 